\title{
PARTISIPASI MASYARAKAT DALAM PROGRAM KEAKSARAAN FUNGSIONAL DI DESA PONDOK BABARIS KECAMATAN SUNGAI PANDAN KABUPATEN HULU SUNGAI UTARA
}

\author{
Norsanti \\ Sekolah Tinggi Ilmu Administrasi (STIA) Amuntai \\ Email: santisabila07@yahoo.com
}

\begin{abstract}
Keaksaraan Fungsional Program is a government policy to reduce amount of illiteracy in Indonesia. A problem that happen in implementation of the program is society participation is still low. The reality is appeared from the low absence of society as the study citizen specially in planting and harvest season. The result of research showed that participation of society in Keaksaraan Fungsional Program in village Pondok Babaris is still limited on participation such as citizen absence while study process and lending places for studying. The factors that influence society participation in Keaksaraan Fungsional Program in village Pondok Babaris are awareness and willingness of society, the education, their economic condition, also facilities and tools of studying.
\end{abstract}

Keywords: society participation, literacy, keaksaraan fungsional program

\section{PENDAHULUAN}

Pendidikan merupakan hal yang sangat penting dalam pembangunan suatu bangsa karena pendidikan menjadi wadah pembentuk karakter bangsa dan juga merupakan cermin peradaban bangsa tersebut. Pendidikan yang berkualitas akan mampu menghasilkan sumber daya manusia yang bisa bersaing dalam skala nasional maupun internasional. Namun saat ini kondisi pendidikan di Indonesia masih menemui banyak masalah diantaranya masih saja ada masyarakat yang terbelakang dengan menyandang status buta aksara. Berdasarkan data Kementerian Pendidikan dan Kebudayaan, jumlah buta aksara di Indonesia hingga akhir tahun 2014 mencapai 6.007 .486 orang. Jumlah ini merupakan 3,76 persen dari total penduduk di Indonesia.

Dengan melihat permasalahan tersebut, maka dalam upaya untuk meningkatkan tingkat keaksaraan di Indonesia, Direktorat Pendidikan Masyarakat telah mengintensifkan pelaksanaan Program Kelompok Belajar Keaksaraan Fungsional berdasarkan Undang-undang No 20 Tahun 2003 tentang Sistem Pendidikan Nasional, Pasal 31 ayat (1) menyebutkan bahwa setiap warga Negara berhak mendapat pendidikan, dan ayat (3) menegaskan bahwa Pemerintah mengusahakan dan menyelenggarakan satu sistem pendidikan nasional yang meningkatkan keimanan dan ketaqwaan serta akhlak mulia dalam rangka mencerdaskan kehidupan bangsa yang diatur dengan undang-undang”. Program Kelompok Belajar Keaksaraan Fungsional merupakan pendidikan luar sekolah (PLS) yang diselenggarakan bagi warga masyarakat penyandang buta aksara untuk menumbuhkan dan mengembangkan kemampuan keaksaraan (membaca, menulis, menghitung, tematik) serta keterampilan fungsional yang dibutuhkan terkait dengan kemampuan keaksaraan itu, sehingga dengan kemampuan keaksaraan itu mereka dapat menguasai pengetahuan dasar yang dibutuhkan dalam masyarakat dan lingkungan kehidupannya.

Pendidikan Luar Sekolah (PLS) sebagai salah satu jalur pendidikan yang ditetapkan oleh pemerintah untuk menghasilkan sosok sumberdaya manusia yang memiliki intelektual, moral dan emosional yang seimbang. PLS merupakan pendidikan di luar jalur sekolah yang disediakan oleh pemerintah untuk masyarakat 
yang tidak bisa mengakses pendidikan formal sehingga jumlah masyarakat buta aksara bisa dikurangi atau bahkan dihapuskan. Salah satu Pendidikan Luar Sekolah (PLS) yang sudah dijalankan pemerintah adalah melalui Program Keaksaraan Fungsional. Program Keaksaraan Fungsional ini juga dilaksanakan di salah satu desa yang ada di Kecamatan Sungai Pandan yaitu Desa Pondok Babaris.

Kecamatan Sungai Pandan terdiri dari 33 Desa salah satunya Pondok Babaris. Desa Pondok Babaris penduduknya 713 orang yang terdiri dari 90 orang penyandang buta aksara. Di pandang dari segi ekonomi memang penghasilan mereka rata-rata di bawah standar. Mereka banyak yang tertinggal di bidang pendidikan, pengetahuan dan keterampilan, itu disebabkan karena banyak yang belum bisa membaca, menulis dan berhitung, dan sebagian lagi tidak menamatkan pendidikan Sekolah Dasar. Ketertinggalan mereka dikarenakan membantu orang tua mencari nafkah dan sibuk dengan pekerjaanya.

Unit Pelaksana Teknis Dinas Pendidikan Kecamatan Sungai Pandan sebagai perpanjangan tangan dari Dinas Pendidikan Kabupaten Kabupaten Hulu Sungai Utara berupaya untuk menggalakkan program Keaksaraan Fungsional salah satunya di Desa Pondok Babaris Kecamatan Sungai Pandan. Sebelum dilaksanakan program ini maka dilakukan sosialisasi dan pendataan terlebih dahulu untuk mengetahui tingkat buta huruf masyarakatnya yang kemudian sebagai acuan untuk menentukan daerah mana yang harus segera dilaksanakan program Pemberantasan Buta Aksara.

Program Keaksaraan Fungsional meliputi program Dasar, lanjutan, pelestarian, usaha mandiri, dan PBH (Pemberantasan Buta Huruf Arab). Namun dalam pelaksanaan pembelajaran masih ditemui kendala yang berkaitan dengan partisipasi masyarakat sebagai peserta program (warga belajar). Karena peserta program sebagian besar berprofesi sebagai petani, maka apabila sudah tiba masa untuk bertani biasanya masyarakat akan sibuk untuk mengurus sawah masing-masing sehingga pelaksanaan pembelajaran tidak berjalan dan terabaikan. Menurut mereka itu lebih penting karena penghasilan mereka sangat tergantung dengan hasil sawahnya yang hanya bisa digarap setahun sekali. Musim penanaman padi sering terjadi bulan Juli-Agustus dan berlanjut dengan panen padi diperkirakan bulan Oktober-November. Kondisi tersebut mengakibatkan tingkat partisipasi masyarakat pada Program keaksaraan masih rendah.

\section{Rumusan Masalah}

Berdasarkan latar belakang yang telah diuraikan di atas, maka penulis tertarik untuk mengetahui bagaimana partisipasi masyarakat dalam Program Keaksaraan Fungsional di Desa Pondok Babaris Kecamatan Sungai Pandan Kabupaten Hulu Sungai Utara dan faktor-faktor apa yang mempengaruhi partisipasi masyarakat dalam Program Keaksaraan Fungsional di Desa Pondok Babaris Kecamatan Sungai Pandan Kabupaten Hulu Sungai Utara.

\section{Tujuan Penelitian}

Berdasarkan rumusan masalah penelitian tersebut, maka dapat dikemukakan tujuan dalam penelitian ini adalah untuk mengetahui partisipasi masyarakat dalam Program Keaksaraan Fungsional di Desa Pondok Babaris Kecamatan Sungai Pandan Kabupaten Hulu Sungai Utara dan untuk menganalisis faktorfaktor yang mempengaruhi partisipasi masyarakat dalam Program Keaksaraan Fungsional di Desa Pondok Babaris Kecamatan Sungai Pandan Kabupaten Hulu Sungai Utara.

\section{TINJAUAN PUSTAKA}

\section{Konsep Partisipasi}

Partisipasi secara umum diartikan sebagai keterlibatan masyarakat untuk memberikan andil (perannya) dalam proses pengambilan keputusan dalam kebijakan pembangunan oleh pemerintah, baik itu negara atau daerah. Menurut Davis, partisipasi adalah keterlibatan mental atau pikiran dan emosi atau perasaan seseorang dalam situasi kelompok yang yang mendorongnya untuk memberikan sumbangan kepada kelompok usaha mencapai tujuan serta turut serta tanggung jawab serta usaha yang bersangkutan. 
Midgley (dalam Muluk, 2007: 49) mendefinisikan partisipasi sebagai keterlibatan masyarakat biasa dalam urusan-urusan setempat secara langsung. Midgley menegaskan bahwa partisipasi masyarakat disebut tercapai apabila program yang diinginkan dan dimanfaatkan oleh masyarakat secara efektif terpelihara oleh masyarakat itu sendiri setelah semua dukungan eksternal berakhir. Partisipasi masyarakat mencakup peran serta masyarakat dalam proses perencanaan, pelaksanaan, evaluasi dan penerimaan manfaat pembangunan dengan mempertimbangkan otonomi dan kemandirian masyarakat.

Conyers (dalam Muluk, 2007: 22) menyimpulkan bahwa keberhasilan dan kegagalan dalam partisipasi masyarakat disebabkan dua hal. Pertama, kesadaran masyarakat bahwa keterlibatannya dapat menentukan hasil akhir dari suatu rencana. Kedua, perasaan bahwa partisipasi mempunyai pengaruh langsung yang dapat dirasakan. Masyarakat tidak akan berminat terhadap aktivitas yang tidak sesuai dengan aspirasi atau yang tidak memiliki pengaruh terhadap perubahan nasib masyarakat.

Wahyudi Kumorotomo (2008: 136-138) mengatakan bahwa partisipasi adalah berbagai corak tindakan massa maupun individual yang memperlihatkan adanya hubungan timbal balik antara Pemerintah dengan warganya. Secara umum corak partisipasi warga Negara dapat dibedakan menjadi empat macam:

a. Partisipasi dalam pemilihan (electoral participation);

b. Partisipasi kelompok (group participation);

c. Kontak antara warga Negara dengan Pemerintah;

d. Partisipasi warga negara langsung.

Partisipasi masyarakat dapat dilihat dari bentuk partisipasi yang diberikan dalam bentuk nyata (memiliki wujud) dan dalam bentuk tidak nyata (abstrak). Bentuk partisipasi yang nyata misalnya uang, harta benda, tenaga dan keterampilan sedangkan bentuk partisipasi yang tidak nyata adalah partisipasi buah pikiran, partisipasi social, pengambilan keputusan dan partisipasi refresentatif. Menurut Huraerah ada beberapa bentuk partisipasi masyarakat yaitu: a. Partisipasi buah pikiran, yang diberikan partisipan dalam bentuk anjang sono, pertemuan atau rapat;

b. Partisipasi tenaga, yang diberikan partisipan dalam berbagai kegiatan untuk perbaikan atau pembangunan desa, pertolongan bagi orang lain dan sebagainya;

c. Partisipasi harta benda, yang diberikan orang dalam berbagai kegiatan untuk perbaikan atau pembangunan desa, pertolongan bagi orang lain yang biasanya berupa uang, makanan dan sebagainya;

d. Partisipasi keterampilan dan kemahiran, yang diberikan orang untuk mendorong aneka ragam bentuk usaha dan industri;

e. Partisipasi sosial, yang diberikan orang sebagai tanda keguyuban.

\section{Program Pembelajaran Keaksaraan Fungsional}

Keaksaraan Fungsional adalah program pengembangan kemampuan seseorang dalam menguasai dan menggunakan ketrampilan membaca, menulis dan berhitung (calistung) kemampuan mengamati dan menganalisa yang berorientasi pada kehidupan sehari-hari dengan memanfaatkan potensi yang ada dilingkungan sekitarnya. Keaksaraan fungsional merupakan suatu metode pendekatan pembelajaran berdesain lokal yang dikembangkan dari bawah ke atas menggunakan suatu proses partisipatif untuk menciptakan model pembelajaran berdesain lokal.

Berdasarkan fungsinya, keaksaraan fungsional adalah model pendekatan yang digunakan di dalam program pemberantasan buta aksara. Program keaksaraan di Indonesia lebih dikenal dengan Program Pendidikan Keaksaraan Fungsional, sehingga secara terminologi (istilah) fungsional dalam keaksaraan, berkaitan erat dengan fungsi dan/atau tujuan dilakukannya Pembelajaran di dalam program pendidikan keaksaraan, serta adanya jaminan bahwa hasil belajarnya benarbenar "bermakna/bermanfaat" atau fungsional bagi "peningkatan mutu dan taraf hidup" warga belajar dan masyarakatnya. Keaksaraan fungsional memiliki suatu tujuan yang lebih dari sekedar kemampuan menulis, membaca dan berhitung, karena kemampuan tersebut akan 
menjadi fondasi bagi kemampuan-kemampuan lainnya.

Program Pendidikan keaksaraan merupakan bentuk layanan Pendidikan Non Formal untuk membelajarkan masyarakat buta aksara, agar memiliki keterampilan CALISTUNG, dan kemampuan fungsional untuk meningkatkan "mutu" dan "taraf" hidupnya. Maka program pendidikan keaksaraan bertujuan untuk:

a. Meningkatkan ketrampilan membaca, menulis dan berhitung warga masyarakat buta aksara, agar melek aksara latin dan angka Arab, serta meningkatkan kemampuan fungsionalnya agar melek bahasa Indonesia dan pengetahuan dasarnya sehingga mutu dan taraf hidupnya menjadi lebih baik.

b. Memecahkan masalah kehidupannya sendiri dan kehidupan masyarakat sekitarnya

c. Membuka jalan untuk mencari atau mendapatkan sumber-sumber kehidupannya

d. Melaksanakan kehidupan sehari-hari secara efektif dan efisien.

e. Mengunjungi dan belajar pada lembaga yang dibutuhkan.

f. Menggali, mempelajari pengetahuan, keterampilan dan sikap pembaharuan untuk ikut berpartisipasi dalam pembangunan.

Adapun strategi yang digunakan dalam pembelajaran keaksaraan fungsional meliputi:

a. Memberikan pembekalan kepada warga belajar

b. Memberikan dorongan kepada warga belajar

c. Memberikan keterampilan membaca, menulis dan menghitung

d. Memberikan semangat kepada warga belajar dengan cara memberikan selingan pada waktu pembelajaran

e. Memberikan alat tulis kepada warga belajar dan memberikan penilaian yang bisa menyelesaikan dengan benar.

Selain itu dalam program pembelajaran keaksaraan fungsional juga ditetapkan kurikulum yang menjadi acuan bagi para tutor/guru dalam penyusunan materi ajar. Kurikulum yang digunakan dalam pembelajaran keaksaraaan fungsional meliputi:

a. Pengenalan huruf vocal (a, i, u, e, o) mengenalkan huruf konsonan $(\mathrm{a}, \mathrm{b}, \mathrm{c}, \mathrm{d}, \mathrm{e})$, merangkai huruf menjadi kata dan membaca kalimat dengan memperhatikan tanda bacaa, selanjtunya diteruskan dengan memperkenalkan tanda baca dengan bunyi yang tepat

b. Melatih dan membiasakan warga belajar dalam menulis kata dan kalimat menggunakan huruf besar dan kecil kemudian menulis kalimat tanpa bantuan orang lain

c. Pengenalan angka misalnya : mengenal angka satuan, puluhan, ratusan dan ribuan selanjutnya diteruskan dengan memperkenalkan keterampilan dimana warga belajar akan dilatih berbagai keterampilan membuat makanan yang nantinya akan membantu ekonomi mereka.

\section{METODE PENELITIAN}

Pendekatan penelitian yang digunakan adalah metode kualitatif. Menurut Kirk \& Miller penelitian kualitatif merupakan penelitian dalam ilmu pengetahuan ilmu sosial yang secara fundamental bergantung pada pengamatan manusia dalam kawasannya sendiri dan berhubungan dengan orang-orang dalam bahasannya dan dalam peristilahannya (Moleong, 2003: 3). Pendekatan ini dipilih untuk menganalisa permasalahan yang berkaitan dengan partisipasi masyarakat dalam Program Keaksaraan Fungsional di Desa Pondok Babaris.

Mengacu pada ragam penelitian kualitatif, maka jenis penelitian yang digunakan bersifat deskriptif. Untuk mendapatkan data yang akurat sebagaimana yang diharapkan maka dilakukan teknik pengumpulan data yang meliputi wawancara secara purposive sampling, dan studi dokumentasi.

Analisa data menggunakan model Miles and Huberman (dalam Sugiyono, 2007 : 246253). Data-data yang dikumpulkan dianalisis melalui beberapa tahapan yaitu data reduction, data display dan conclusion drawing/verification sehingga dapat diambil suatu kesimpulan. 


\section{HASIL DAN PEMBAHASAN}

\section{Gambaran Umum Desa Pondok Babaris}

Desa Pondok Babaris adalah salah satu desa di Kecamatan Sungai Pandan, Kabupaten Hulu Sungai Utara Provinsi Kalimantan Selatan Indonesia. Pondok Babaris adalah daerah yang keseluruhanya rawa, mata pencaharian penduduk rata-rata bertani dan menangkap ikan jarak ke ibu kota Kecamatan $20 \mathrm{Km}$. Pondok Babaris termasuk desa yang terpencil dan tertinggi karena akses transportasi yang masih sulit dan belum dialiri oleh jaringan listrik, penduduk hanya menggunakan PLTS (Pembangkit Listrik Tenaga Surya).

Luas wilayah Desa Pondok Babaris 4,5 km. Terdiri 4 Rukun Tetangga (RT). Adapun jumlah penduduk sebanyak 713 orang yang terdiri dari laki-laki 388 orang dan perempuan 325 orang dengan KK 178. Untuk lebih jelasnya dapat dilihat pada tabel berikut:

Tabel 1. Data Jiwa Desa Pondok Babaris

\begin{tabular}{cccccc}
\hline No. & Uraian & Laki-laki & Perempuan & Jumlah & \% \\
\hline 1 & $0-11$ bulan & 10 & 4 & 14 & 2,0 \\
2 & $1-4$ tahun & 32 & 22 & 54 & 8,5 \\
3 & $5-14$ tahun & 83 & 74 & 157 & 22,5 \\
4 & $15-59$ tahun & 247 & 214 & 461 & 62,3 \\
5 & 60 tahun ke atas & 16 & 11 & 27 & 4,7 \\
\hline \multicolumn{7}{l}{ Jumlah } & 388 & 325 & 713 & 100 \\
\hline \multicolumn{5}{l}{ Sumber: Profil Desa Pondok Babaris, 2015} \\
\end{tabular}

Desa Pondok Babaris tingkat pendidikan masyarakat rata-rata berpendidikan tingkat SD dan sebagian kecil ada yang tamat SLTP dan
SLTA. Untuk jelasnya dapat dilihat pada tabel sebagai berikut:

Tabel 2. Tingkat Pendidikan Masyarakat Desa Pondok Babaris

\begin{tabular}{clr}
\hline No. & Tingkat Pendidikan & Jumlah \\
\hline 1 & Buta Huruf & 90 orang \\
2 & Tidak tamat SD & 53 orang \\
3 & SD & 499 orang \\
4 & SLTP & 45 orang \\
5 & SLTA & 52 orang \\
6 & Diploma/ Sarjana & 9 orang \\
\hline
\end{tabular}

Sumber: Profil Desa Pondok Babaris, 2015

Berdasarkan tabel di atas dapat diketahui masyarakat yang buta huruf sebanyak 90 orang, tidak tamat SD 53 orang, SD 499 orang, SLTA 52 orang, dan sarjana sebanyak 9 orang. Dari data tersebut dapat terlihat bahwa jumlah masyarakat yang buta huruf di Desa Pondok Babaris masih tinggi yaitu 90 orang, sehingga sangat diperlukan upaya untuk mengurangi jumlah masyarakat yang masih buta huruf.

Untuk mendukung lancarnya pendidikan masyarakat, di Desa Pondok Babaris telah berdiri TK, TPA, SD dan Madrasah dengan dilengkapi beberapa tenaga pengajar baik tenaga honorer maupun PNS. Untuk lebih jelasnya dapat dilihat pada tabel sebagai berikut: 
Tabel 3. Sarana dan Prasana Pendidikan

\begin{tabular}{clccc}
\hline \multirow{2}{*}{ No. } & \multirow{2}{*}{ Sarana Pendidikan } & \multirow{2}{*}{ Buah } & \multicolumn{2}{c}{ Tenaga Pengajar } \\
\cline { 4 - 5 } & & 1 & PNS & Honor \\
\hline 1 & TK/ RA & 1 & - & 5 \\
2 & TPA & - & - & 15 \\
3 & SD & 1 & 3 & - \\
4 & Madrasah & 12 \\
\hline
\end{tabular}

Sumber: Profil Desa Pondok Babaris, 2015

Berdasarkan tabel 3 dapat diketahui bahwa sarana pendidikan di Desa Pondok Babaris Kecamatan Sungai Pandan Kabupaten Hulu Sungai Utara TK/ RA sebanyak 1 buah, TPA 1 buah, sedangkan SD tidak ada dan Madrasah sebanyak 1 buah.

\section{Partisipasi Masyarakat Dalam Program Keaksaraan Fungsional Di Desa Pondok Babaris}

Keberhasilan suatu program pembangunan memerlukan dukungan semua pihak baik pemerintah dan juga masyarakat. Masyarakat sebagai objek pembangunan sangat diperlukan partisipasinya untuk bisa memberikan masukan dan koreksinya terhadap berbagai program yang dijalankan oleh pemerintah karena secara prinsip pembangunan ditujukan untuk mewujudkan kesejahteraan masyararakat. Demikian pula dalam pelaksanaan Program Keaksaraan Fungsional di Desa Pondok Babaris, partisipasi masyarakat mutlak diperlukan karena masyarakatlah yang menjadi sasaran program tersebut.

Secara umum partisipasi masyarakat diartikan sebagai keterlibatan masyarakat dalam program pembangunan. Berdasarkan wawancara dengan beberapa orang tutor (guru) dan masyarakat peserta Program Keaksaraan Fungsional, maka dapat diketahui partisipasi masyarakat masih terbatas pada kehadiran pada program pembelajaran dan partisipasi berupa peminjaman sarana belajar.

1. Partisipasi masyarakat berupa kehadiran pada program pembelajaran

Program Keaksaraan Fungsional dilaksanakan dalam 3 tahapan yaitu tahap dasar/ pemberantasan, tahap pembinaan dan tahap pelestarian. Tahap-tahap ini menjelaskan tentang kemajuan warga belajar sesuai dengan harapan tujuan keaksaraan fungsional:

a. Pemberantasan, menggambarkan warga belajar yang belum memiliki keterampilan dasar. Dalam hal ini, tutor perlu membantu warga belajar mengatasi ketidakmampuan membaca dan menulis sendiri, serta mengembangkan keterampilan dasarnya dalam kegiatan belajar mengajar yang fungsional, sesuai dengan minat dan kebutuhan warga belajar.

b. Pembinaan, menggambarkan warga belajar yang sudah memiliki keterampilan dasar membaca dan menulis dengan lancar, memiliki pengetahuan dan pengalaman. Pada tahap ini, tutor dapat membantu warga belajar dengan menggunakan bahan belajar dari kehidupan sehari-hari dan membantu mereka mengembangkan kemampuan fungsionalnya.

c. Pelestarian, menggambarkan pembentukan sikap warga belajar agar dapat terus belajar. Pada tahap ini, diharapkan warga belajar dapat memecahkan masalah dan mencari informasi serta nara sumber sendiri. Sedangkan peran tutor membantu warga belajar dalam mengembangkan kemampuan seperti dalam memilih topik belajar, membuat rencana belajar, menulis laporan, dan sebagainya.

Masing-masing tahap pembelajaran berlangsung selama 6 bulan, sedangkan dalam pelaksanaanya peserta program dibagi menjadi 6 kelompok belajar dan setiap kelompok dibatasi 15 orang. Nama - nama dari kelompok belajar tersebut yaitu : Kenanga, Plamboyan, Dahlia, Nusa Indah, 
Matahari, Cempaka. Kegiatan belajar setiap kelompok diadakan tiga kali seminggu, sesuai dengan jadwal yang sudah disepakati oleh warga belajar.

Adapun keadaan warga belajar pada pembelajaran Keaksaraan Fungsional di Desa Pondok Babaris Kecamatan Sungai Pandan Kabupaten Hulu Sungai Utara tahun pelajaran 2014/ 2015 yang terdaftar berjumlah 90 warga belajar dengan perincian laki-laki 33 dan perempuan 57. Hal ini dapat dilihat melalui tabel jumlah warga belajar pada masing-masing kelompok kejar dibawah ini :

Tabel 4. Daftar Warga Belajar Kelompok Kejar

\begin{tabular}{clccc}
\hline No. & Kelompok Kejar & Laki-laki & Perempuan & Pekerjaan \\
\hline 1 & Kenanga & 3 & 12 & Tani \\
2 & Plamboyan & 3 & 12 & Tani \\
3 & Dahlia & 7 & 8 & Tani \\
4 & Nusa Indah & 5 & 10 & Tani \\
5 & Matahari & - & 15 & Tani \\
6 & Cempaka & 15 & - & Tani \\
\hline
\end{tabular}

Sumber: UPT Disdik Kecamatan Sungai Pandan, 2015

Pelaksanaan program Keaksaraan Fungsional yang dijadwalkan tiap tahap harus memenuhi target, namun pada kenyataanya masih belum sesuai dengan apa yang telah ditargetkan oleh penyelenggara karena masih terdapat kendala. Salah satu kendala dalam pelaksanaan program adalah tingkat kehadiran peserta (warga belajar). Menurut beberapa orang tutor (guru), tingkat kehadiran warga belajar cukup baik, ada sebagian warga belajar yang memiliki motivasi untuk bisa membaca dan menulis sehingga mereka selalu mengusahakan hadir kecuali ada kendala misalnya hujan atau kesibukan mereka. Kesibukan yang dimaksud disini adalah kalau perempuan sebagai ibu rumah tangga yang kadang tidak bisa meninggalkan rumah karena mengurus anaknya dan kalau laki-laki biasanya karena pekerjaan mereka di sawah terutama bila sudah tiba musim tanam dan musim panen. Namun ada juga sebagian warga belajar yang memiliki motivasi belajar yang sangat rendah sehingga tidak menepati jadwal pembelajaran yang sudah ditetapkan karena mereka tidak merasa rugi kalau tidak mengikuti pembelajaran.

Menurut para tutor untuk meningkatkan kehadiran warga belajar sudah dilakukan berbagai upaya seperti memberikan pengarahan tentang pentingnya belajar, menyediakan konsumsi sewaktu proses pembelajaran dan terkadang waktu belajar juga disesuaikan dengan keinginan atau kesibukan mereka.

2. Partisipasi masyarakat berupa peminjaman sarana (tempat) belajar

Partisipasi masyarakat dalam Program Keaksaraan Fungsional juga dapat dilihat dari bantuan dalam bentuk sarana belajar, seperti meminjamkan rumah atau tempat ibadah (musholla) untuk dipakai sebagai tempat belajar. Peminjaman tempat belajar dari masyarakat sangat membantu dalam pelaksanaan program ini karena Desa Pondok Babaris merupakan desa yang agak terpencil karena jaraknya agak jauh dari kota. Desa Pondok Babaris bisa dicapai melalui jalan darat dan air. Untuk jalan darat jaraknya agak jauh dan jalan yang dilalui pun merupakan jalan berbatu sehingga masyarakat lebih suka lewat jalur air dengan memakai perahu 
(jukung) karena jaraknya lebih dekat untuk mencapai desa. Dengan adanya peminjaman sarana belajar dari masyarakat maka warga

Dari hasil penelitian tersebut maka dapat disimpulkan bahwa partisipasi masyarakat masih terbatas pada kehadiran dan peminjaman tempat belajar. Mengutip pendapat Huraerah, maka partisipasi masyarakat dalam Program Keaksaraan Fungsional dapat dikategorikan sebagai partisipasi tenaga dan partisipasi harta benda. Partisipasi tenaga merupakan partisipasi yang diberikan partisipan dalam berbagai kegiatan untuk perbaikan atau pembangunan desa, pertolongan bagi orang lain dan sebagainya. Partisipasi harta benda merupakan partisipasi yang diberikan orang dalam berbagai kegiatan untuk perbaikan atau pembangunan desa, pertolongan bagi orang lain yang biasanya berupa uang, makanan dan sebagainya.

Pelaksanaan Program Keaksaraan Fungsional sangat memerlukan partisipasi masyarakat karena program ini memang ditujukan kepada masyarakat terutama mereka yang masih buta aksara. Keberhasilan program ini dapat dinilai dari kemampuan warga belajar dalam membaca, menulis dan berhitung (calistung). Oleh karena itu agar kemampuan calistung warga belajar meningkat maka sangat diperlukan keaktifan (partisipasi) mereka dalam program ini. Partisipasi masyarakat dalam program keaksaraan fungsional ini tentunya tidak berdiri sendiri tetapi juga dipengaruhi oleh faktor-faktor lain. Maka berdasarkan wawancara dengan beberapa orang tutor/guru yang mengajar pada kelompok belajar, ada beberapa faktor yang mempengaruhi partisipasi masyarakat dalam program Keaksaraan Fungsional pada Desa Pondok Babaris yaitu:

1. Faktor kesadaran/kemauan masyarakat. Menurut para tutor/guru yang mengajar pada program Keaksaraan Fungsional, kesadaran masyarakat untuk ikut program masih perlu ditingkatkan lagi karena terkadang kemauan masyarakat untuk belajar mengalami penurunan apalagi kalau mereka ada pekerjaan atau kesibukan lain sehingga tutornya harus mendatangi ke rumah mereka untuk mengajak mereka agar ikut belajar lagi. Untuk meningkatkan kesadaran masyarakat tentang pentingnya pendidikan belajar sangat terbantu karena mereka tidak perlu menempuh jarak yang jauh untuk belajar.

sudah dilakukan misalnya dengan memberikan pengarahan kepada masyarakat pada rapat desa atau dengan mendatangkan petugas dari UPT Dinas Pendidikan Sungai Pandan;

2. Faktor pendidikan, sebagian besar masyarakat desa Pondok Babaris masih rendah pendidikannya dimana rata-rata mereka berpendidikan SD dan sebagian kecil ada yang tamat SLTP dan SLTA. Kondisi tersebut mengakibatkan mereka tidak memahami pentingnya pendidikan bagi kehidupan mereka;

3. Faktor ekonomi, sebagian besar masyarakat desa Pondok Babaris bermata pencaharian sebagai petani, nelayan dan buruh. Mata pencaharian masyarakat tersebut bersifat musiman sehingga tidak mengherankan warga belajar sering tidak hadir pada pembelajaran karena mereka lebih mengutamakan pekerjaannya. Misalnya kalau warga belajar mata pencahariannya dari bertani maka bisa dipastikan kalau sudah tiba musim tanam dan musim panen mereka akan lebih mengutamakan bekerja di sawah dari pada ikut belajar. Menurut para tutor (guru) biasanya kalau sudah musim gawi (bekerja) pembelajaran akan diliburkan karena warga belajar banyak yang tidak datang;

4. Sarana dan Fasilitas belajar. Sarana dan fasilitas belajar merupakan salah satu faktor yang berpengaruh dalam partisipasi masyarakat, pengadaan fasilitas yang layak, seperti gedung, tanah dan peralatan belajar akan membuat masyarakat termotivasi untuk mengikuti program pembelajaran. Sarana belajar berupa tempat/ruang belajar dalam Program Keaksaraan Fungsional masih belum tersedia, biasanya pembelajarana dilakukan dengan meminjam rumah penduduk atau menggunakan fasilitas umum seperti sekolah atau musholla. Adapun untuk fasilitas belajar seperti alat tulis, modul dan bahan ajar lainnya sudah disediakan oleh pemerintah. Dana ini diperoleh dari APBD dengan mengajukan proposal kepada Pemda. 


\section{PENUTUP}

\section{Kesimpulan}

Berdasarkan penelitian yang telah dilakukan dapat disimpulkan sebagai berikut:

a. Partisipasi masyarakat dalam Program Keaksaraan Fungsional pada desa Pondok Babaris masih terbatas pada partisipasi tenaga berupa kehadiran pada proses belajar dan partisipasi harta benda berupa peminjaman tempat belajar.

b. Faktor-faktor yang mempengaruhi partisipasi masyarakat dalam Program keaksaraan Fungsional pada desa Pondok Babaris adalah kesadaran/kemauan masyarakat, pendidikan masyarakat, kondisi ekonomi masyarakat serta fasilitas dan sarana belajar.

\section{REFERENSI}

Indrawijaya, Adam Ibrahim \& Juni Pratono, 2011. Revitalisasi Administrasi Pembangunan (Berbasis Jatidiri dan Karakter Bangsa dalam Pembangunan Nasional). Bandung: Alfabeta.

Kumorotomo, Wahyudi, 2008. Etika Administrasi Negara. Jakarta: PT RajaGrafindo Persada.

Laksana, Nuring Septyasa. 2013. Bentuk-Bentuk Partisipasi Masyarakat Desa dalam Program Desa Siaga Di Desa Bandung Kecamatan Playen Kabupaten Gunung Kidul Provinsi Daerah Istimewa Yogyakarta. Jurnal Kebijakan dan Manajemen Publik Vol 1 No. 1 Januari 2013 (versi online.

Moleong, J. Lexi, 2000. Metodologi Penelitian Kualitatif. Bandung: al Fabeta.

Muluk, Khairul, 2007. Menggugat Partisipasi Publik dalam Pemerintahan Daerah (Sebuah Kajian dengan Pendekatan Berpikir Sistem).

Malang: Bayumedia Publishing.

Sugiyono, 2007. Metode Penelitian Kuantitatif, Kualitatif dan $R \& D$. Bandung : al Fabeta.
Sugiyono, 2007. Metode Penelitian Kuantitatif, Kualitatif dan $R \& D$. Bandung : al Fabeta. 